\title{
DIGITAL LITERACY OF PRIMARY EDUCATION TEACHERS IN THE AREA OF DIGITAL SAFETY
}

\author{
Lukasz Tomezyk \\ Institute of Educational Science, Pedagogical University of Cracow (Poland)
}

\begin{abstract}
Digital Literacy (DL) is one of the key competencies modern teachers should have. Regardless of the stage of education, they should be skilled in using modern ICT solutions. Fluent use of digital media is one of the DL components - as much important as the ability to understand and anticipate online threats. DL of teachers determines not only their own safety but also the safety of children in elementary education. The paper sets out to address the following question: What is the level of digital literacy regarding e-threats among primary school teachers? The answer was given based on a competence tests and a diagnostic survey results. The research was conducted among 222 teachers in Poland and was commissioned by the Ministry of National Education (project executor: Cities on the Internet Association Tarnów and Navigo Wroclaw). It is the first research based on a real measurement of DL in the following areas: ergonomics of using ICT, reliable evaluation of online information, influence of advertising on children, relationships with other people through the Internet, setting logins and passwords, and malware protection. The conclusion are surprising: teachers have insufficient knowledge regarding protection of children against e-communication threats but their competencies regarding malware protection are relatively high. Particular support in strengthening DL should be provided to trainees, that is, teacher who begin their professional career.
\end{abstract}

Keywords: Digital literacy, teachers, primary education, safety, internet.

\section{Introduction - the need to analyze digital literacy in the light of digital safety}

Internet has become the key element supporting different areas of our daily functioning. Fluent navigating through new media requires proper competencies. This type of skills is called digital literacy (DL). With the popularization of the Internet and, in consequence, networked services, DL has become as crucial as reading, writing, numeration, fluency in foreign and native languages, team work and entrepreneurship. However, we need to point out that as a whole, DL involves not only technical abilities, but also ability to anticipate threats related to the online services (Tomczyk, 2008).

Different risks, both at individual and social level, like frauds, fake news, addictions, cyberbullying or exposure to harmful content has become the challenge for the information society. There are groups which are particularly susceptible to the dangers of the digital world. An important strategic element in fighting these threats is media education focused on improving the DL level. Over the years, we can notice the great increase in the number of research on the digital threats among children and youth, and proposed solutions to raise the level of digital safety among students (Lee, 2018). DL are more and more often mentioned, already at the pre-school educational level (Tecce DeCarlo et al., 2018). Nevertheless, the holistic approach to digital safety requires analyses of the family (Tomczyk, 2018) and school environment. Parents are the first adults responsible for the digital safety of the youngest users. They do it by modelling proper behaviours and introducing adequate media education and socialisation (Creer, 2018). These activities are then complemented by teachers. However, effective media education requires competent teachers who are prepared to implement adequate measures to prevent the present digital threats (Stošić, Stošić, 2015; Del Rey et al., 2015). This prevention, based on the formal education, begins already at the early education stage. It is necessary as the age of the first contact with the new media decreases systematically and home environments are saturated with devices connected to the Internet. 


\section{Methods}

The objective of the study was to present knowledge and skills that constitute the digital literacy of teachers in grades 1-3 (integrated primary education, first education cycle) regarding digital safety. The research fit into the risk paradigm in media pedagogy in Poland, that is, they focus on analyzing the positive influence of media (e.g. increased effectiveness of learning and teaching) but also the negative consequences connected with protecting children from media-related risks.

The study was conducted in a group of 222 teachers in Poland, in the 2 nd half of 2016. The sample included primary school teachers - first education cycle (integrated primary education). The sampling was carried out by the external agency NAVIGO, commissioned by the Cities on the Internet Association (Stowarzyszenie Miasta w Internecie, SMWI) from Tarnow (Tomczyk, Srokowski, Wąsiński, 2016). The research was financed by the Polish Ministry of National Education within the program Bezpieczna+ (Safety+). Each teacher filled in the knowledge and competence test which measured their level of DL in the following areas: ergonomics of using the digital tools, assessment of credibility of online information, influence of advertisements on children safety, threats resulting from interactions with other Internet users, ability to secure logins and passwords and safe logging, and protection against viruses. Each of the above areas was measured using 3 testing questions (18 questions total). The presented results are innovative because the test measured the real level of knowledge and skills, whereas previous analyses were based on respondents' declarations. The knowledge test (up to 100\% correct answers possible) was supplemented with the diagnostic survey measuring the attitudes towards the new media and showing the socio-demographic characteristics of the sample (independent variables). The study was conducted compliant to the principles of social research ethics, were anonymous and voluntary.

There were $96.44 \%(\mathrm{~N}=217)$ women and $3.56 \%(\mathrm{~N}=8)$ men - teachers in the first education cycle. The vast majority of the respondents were females because Polish education system is dominated by women, especially at the primary and pre-school level. The most respondents were teaching in village schools $(50.2 \%)$, then in: town with population up to $50,000(21.3 \%)$, city with more than 200,000 residents $(12.4 \%)$, city with population of $50-100,000(10.7 \%)$, city with population of $100-200,000$ $(5.3 \%)$. The respondents' professional experience varied - the average number of years at work was $20.7(\mathrm{SD}=10.88)$, median 24 . The average age of the surveyed teachers was $43.95(\mathrm{SD}=10.31)$ and is very similar to the data regarding the whole education industry in Poland.

\section{Results}

The interviewed pre-school teachers show diverse levels of knowledge and skills in the area of digital safety. The strongest DL components are: ergonomics of using the new media and protection against malware, whereas the weakest element is protection against unsafe online interactions, assessment of credibility of online information and influence of online advertisements on children. The technical aspects of DL are slightly more advanced than the social aspects of digital media influence. Figure 1 presents the percentage distribution of the competence test results.

Figure 1. Percentage distribution of average correct answers related to 6 areas of digital safety.

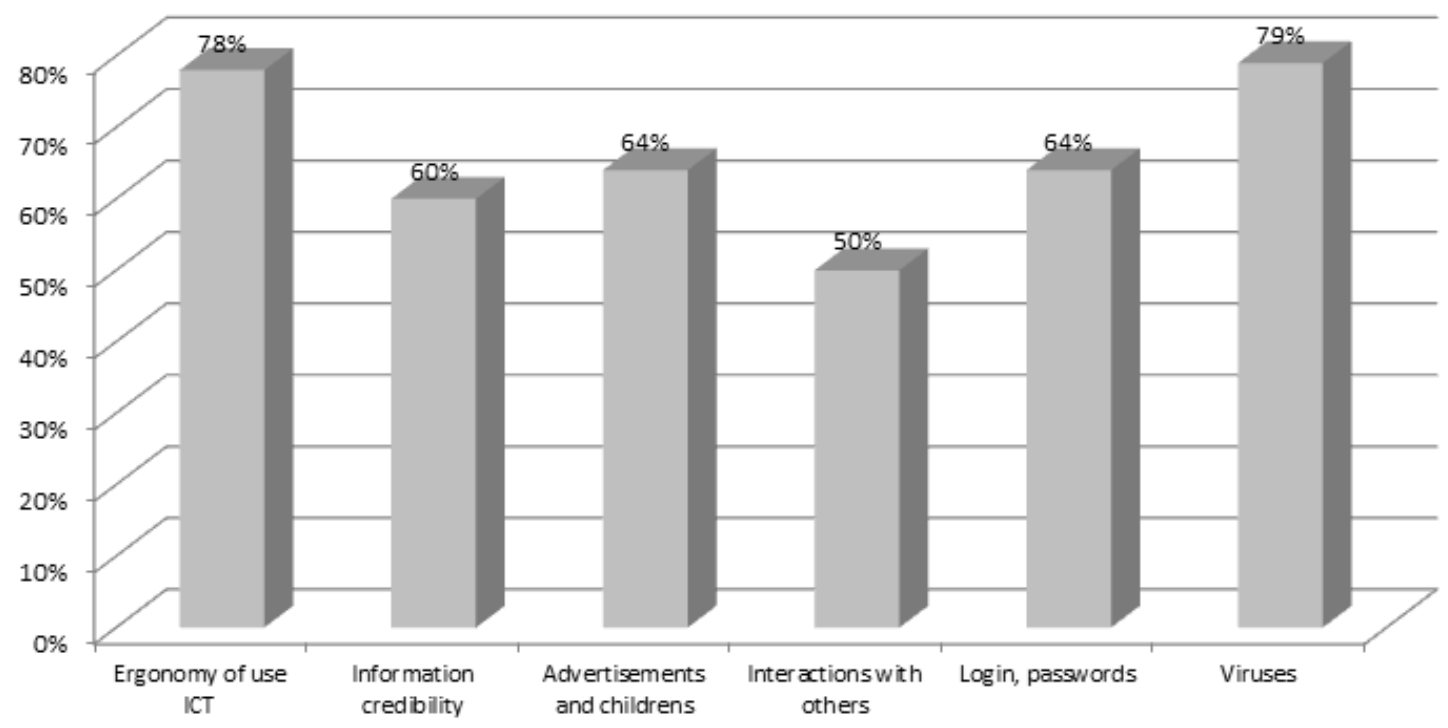


The diverse results are determined by several factors. For example, the higher results were obtained by: men $\mathrm{F}(1,223)=4.0959, \mathrm{p}=.04418$, teachers from school where digital safety procedures have been introduced $\mathrm{F}(2,222)=4.9239, \mathrm{p}=.00808$, respondents declaring there has been a case of violation of the digital safety in their school $\mathrm{F}(2,222)=4.2467, \mathrm{p}=.01549$, teachers who positively evaluate the possibilities of using ICT in education $\mathrm{F}(4,220)=3.3142$, $\mathrm{p}=.01162$, teachers who highly evaluate their DL level $F(4,220)=3.5156, p=.00834$. The established rules of using the new media in a classroom and the frequency of classes addressing the problem of e-threats are not related to the competence test results. We also noticed that the older respondents, the less knowledge they have about the digital threats ( $\mathrm{r} 2=-.2040, \mathrm{p}<0.002)$ - Fig. 2. In addition, the more years of professional experience, the lower results of the competency test $(\mathrm{r} 2=-.109, \mathrm{p}<0.1)$, however this correlation is not statistically significant.

Figure 2. Relation between age $(x)$ and competence test results (y).

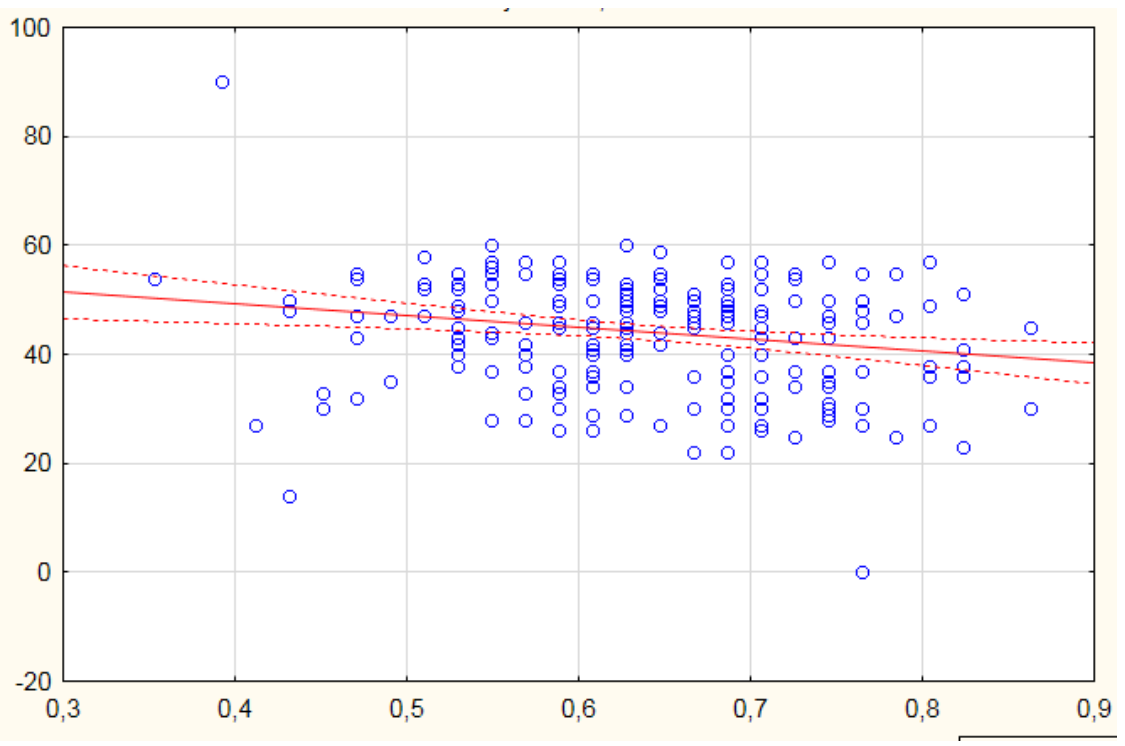

The comparison of the areas of the digital safety is also interesting. Knowledge in one area does not translate directly into the expertise in another DL areas. There is one exception: correlations regarding the soft skills like ability to recognise online advertisements and their impact on children and understanding the threats resulting from online interactions (in particular, with strangers). We also noticed that the high level of technical knowledge about protecting the digital devices against, for example, viruses, does not determine the knowledge and skills in the areas of social aspects of the e-threats. The detailed relations are presented in Table 1.

Table 1. Relationship between the DL components.

\begin{tabular}{|l|c|c|c|c|c|}
\hline & Ergonomy of use ICT & $\begin{array}{c}\text { Information } \\
\text { credibility }\end{array}$ & Advertisements & $\begin{array}{c}\text { Interactions with } \\
\text { others }\end{array}$ & Viruses \\
\hline $\begin{array}{l}\text { Information } \\
\text { credibility }\end{array}$ &, 0905 & 1,0000 & & & \\
\hline Advertisements &, $1427^{*}$ &, $1564 * *$ & 1,0000 & & \\
\hline $\begin{array}{l}\text { Interactions with } \\
\text { others }\end{array}$ &, $1346^{*}$ &, 0588 &, $2640 * * *$ & 1,0000 & \\
\hline Viruses &,- 0008 &, 0812 &, 0648 &, $2262^{* *}$ & 1,0000 \\
\hline
\end{tabular}

$*<0.05, * *<0.001, * * *<0.0001$

\section{Discussion}

DL has become one of the key competencies for modern people. In the age of the development of digital services, the problem of digital safety becomes particularly important (Pyżalski, 2012). Skills and knowledge related to the technical securing the new media and understanding of the risk mechanisms in the digital world are the key element of DL (Kopecky et al., 2015). The scale of e-threats among the youngest Internet users has increased visibly during the recent years (Kopecký et al. 2015). The primary 
responsibility for the protection against risky behaviours and situations belongs to the family members and then professionally equipped teaching staff (Frania, 2014). One of the important factors improving the digital safety in schools is the high DL level among teachers, developed through their formal education (university studies), non-formal (trainings) and incidental (self-education) (Tureckiová, Veteška, 2011; Stosic, Velickovic, 2013).

Based on the data collected, we noticed the diverse level of knowledge, skills and basics regarding the digital safety. The weakest areas: recognizing false and true information and understanding the mechanisms of risky online interactions are the areas which require particular improvement (Szotkowski, 2010). Not only teachers, but also other social and professional groups are at risk of disinformation. Minimization of hoax is becoming the common challenge at the present stage of information society development (Bajarin, 2018; Ravitch, 2014). An example which can confirm the above statement is the panic stirred by media and misinformation among the pedagogues regarding the online blue whale challenge (Yılmaz, Candan, 2018; Irina et al., 2017). Information about this non-existing game has become an example of media disinformation — shared with noble intent, which affected mostly pre-school teachers.

Our data show another important aspect of DL. This new type of literacy is heterogeneous and consists of many inter-related areas of knowledge and skills. DL is a hybrid of technical skills and knowledge of the social consequences of new media influence (Ziemba, 2014). In addition, both technical abilities and knowledge in the area of the digital safety must be constantly updated due to the dynamic nature of the online reality.

\section{Conclusions}

Digital safety of children and youth has become one of the research priorities in media pedagogy and school practice (Potyrała, 2017). Based on the selected risk paradigm connected with the noticeable growth of the scope of e-threats, the problem of adequate DL is one of the significant factors which protect against the threats of the digital world. The priority of eliminating the e-threats is visible in the number of studies and publications regarding online threats (the scientific aspect) as well as the vast offer of trainings addressed to teachers (preventive aspect). The analysis of DL in the context of primary education becomes particularly important when we consider the fact that teachers and parents are the ones who bear the main responsibility for modelling the habits of safe media use among the young users.

\section{References}

Bajarin, T. (2018). How Do You Fight Fake News? Start with the Kids. PC Magazine, 45.

Creer, A. (2018). Introducing Everyday "Digital Literacy Practices" into the Classroom: An Analysis of Multi-Layered Media, Modes and Their Affordances. Journal of New Approaches in Educational Research, 7(2), 131-139.

Del Rey, R., Casas, J. A., Ortega-Ruiz, R., Schultze-Krumbholz, A., Scheithauer, H., Smith, P., ... Plichta, P. (2015). Structural validation and cross-cultural robustness of the European Cyberbullying Intervention Project Questionnaire. Computers in Human Behavior, 50, 141-147. doi:10.1016/j.chb.2015.03.065

Frania, M. (2014). Media Education. Perspectives of Innovations, Economics \& Business, 14(2), 109-112. https://doi.org/10.15208/pieb.2014.13

Irina, V., Shuanat, K., Natalya, R., \& Leila, A. (2017). From the Silent House Meme to the Blue Whale-Game: The Storyworld's Transformation. International Multidisciplinary Scientific Conference on Social Sciences \& Arts SGEM, 253-260. https://doi.org/10.5593/sgemsocial2017/4

Kopecký, K., Hejsek, L., Kusá, J., Řeřichová, V., \& Mareš ová, H. (2015). Specifics of Children Communication and Online Aggressors within the Online Assaults on Children (Analysis of Selected Utterances). International Multidisciplinary Scientific Conference on Social Sciences \& Arts SGEM, 195-202.

Kopecký, K., Szotkowski, R., \& Krejčí, V. (2015). Rizikové formy chování českých a slovenských dětí v prostředi internetu. doi:10.5507/pdf.15.24448619

Lee, N. M. (2018). Fake News, Phishing, and Fraud: A Call for Research on Digital Media Literacy Education beyond the Classroom. Communication Education, 67(4), 460-466.

Potyrała, K. (2017). iEdukacja. Synergia nowych mediów i dydaktyki. Ewolucja - antynomie - konteksty. doi: $10.24917 / 9788380840522$

Pyżalski, J. (2012). From cyberbullying to electronic aggression: typology of the phenomenon. Emotional \& Behavioural Difficulties, 17(3/4), 305-317. https://doi.org/10.1080/13632752.2012.704319 
Ravitch, D. (2014). Hoaxes in Educational Policy. Teacher Educator, 49(3), 153-165.

Stošić, L., \& Stošić, I. (2015). Perceptions of teachers regarding the implementation of the internet in education. Computers in Human Behavior, 53, 462-468. doi:10.1016/j.chb.2015.07.027

Stosic, L., \& Velickovic, D. (2013). Computer security and security technologies. Journal of Process Management. New Technologies, 1(1), 14-19. doi:10.5937/jpmnt1301014s

Szotkowski, R. (2010). Dangerous behavior of children and youth in the Internet and possibility of their protection. Journal of Technology and Information, 2(1), 110-114. doi:10.5507/jtie.2010.024

Tecce DeCarlo, M. J., Grant, A., Lee, V. J., \& Neuman, D. (2018). Information and Digital Literacies in a Kindergarten Classroom: An I-LEARN Case Study. Early Childhood Education Journal, 46(3), 265-275

Tomczyk, Ł. (2018). Digital competences of parents in the matter of electronic threats. SHS Web of Conferences, 48, 01004. doi:10.1051/shsconf/20184801004

Tomczyk, Ł., Srokowski, Ł. \& Wąsiński, A. (2016). Kompetencje w zakresie bezpieczeństwa cyfrowego w polskiej szkole. Tarnów: Stowarzyszenie Miasta w Internecie.

Tureckiová, M., \& Veteška, J. (2011). Význam kvalifikací a kompetencí v profesním vzdělávání dospělých. Smíšený Design v Pedagogickém Výzkumu. Sborník Příspěvků z 19. Výroční Konference České Asociace Pedagogického Výzkumu. doi:10.5817/pdf.p210-capv-2012-79

Yılmaz, M., \& Candan, F. (2018). Oyun Sanal İntihar Gerçek: "The Blue WhaleChallange/Mavi Balina" Oyunu Üzerinden Kurulan İletişimin Neden Olduğu İntiharlar Üzerine Kuramsal Bir Değerlendirme. Akdeniz Iletisim, 266-279

Ziemba, E. (2014). Discussion on a Sustainable Information Society. Business Informatics / Informatyka Ekonomiczna, 1(31), 13-25. https://doi.org/10.15611/ie.2014.1.01 